NBER WORKING PAPER SERIES

\title{
INVESTMENT PLANS AND STOCK RETURNS
}

\author{
Owen Lamont
}

Working Paper 6973

http://www.nber.org/papers/w6973

\author{
NATIONAL BUREAU OF ECONOMIC RESEARCH \\ 1050 Massachusetts Avenue \\ Cambridge, MA 02138 \\ February 1999
}

I thank the Center for Research in Security Prices, the FMC Faculty Research Fund at the Graduate School of Business, University of Chicago, and the National Science Foundation for financial support. I thank Amy C. Ko, Lawrence Leung, David Robinson, and Eric Wang for research assistance. I thank John Cochrane, Simon Gilchrist, Charles Himmelberg, Anil Kashyap, and workshop participants at the American Economic Association Meetings, the NBER Corporate Finance meeting, the University of Chicago, and the University of Wisconsin for helpful discussions. Any views expressed in this paper are those of the author only and not those of the National Bureau of Economic Research.

1999 by Owen Lamont. All rights reserved. Short sections of text, not to exceed two paragraphs, may be quoted without explicit permission provided that full credit, including ${ }^{\circledR}$ notice, is given to the source. 
Investment Plans and Stock Returns

Owen Lamont

NBER Working Paper No. 6973

February 1999

JEL No. E22, E44, G12, G31

\begin{abstract}
Capital expenditure plans at the beginning of the year, from a US government survey of firms, explain more than three quarters of the variation in real annual aggregate investment growth between 1948 and 1993. The negative correlation of contemporaneous investment and stock returns is explained by the negative correlation of planned investment and subsequent stock returns. Unexpected revisions to aggregate investment (actual minus plan) within a year are essentially unrelated to current stock returns, and positively related to current profits. Revisions to industry investment are positively related to industry-specific stock returns and to aggregate profits.
\end{abstract}

Owen Lamont

Graduate School of Business

University of Chicago

1101 East 58th Street

Chicago, IL 60637

and NBER

owen.lamont@gbs.uchicago.edu 


\section{Introduction}

Asset prices both reflect and affect future economic activity. But the connection between financial market prices and the real economy is often difficult to discern. In particular, it is unclear to what extent the stock market affects corporate investment in physical capital. Such investment is a volatile part of business cycle fluctuations.

This paper uses investment plans to investigate the determinants of annual investment growth at the aggregate and industry level. Between 1947 and 1993, the Commerce Department conducted a survey of capital expenditure plans. It asked firms their planned expenditure on plant and equipment over the coming year. It then aggregated the survey responses to produce estimates of industry and aggregate investment plans.

These investment plans are not unbiased forecasts of future investment. However, plans are quite informative: more than three quarters of the annual variation in aggregate investment growth is explained by investment plans made at the beginning of the year, and plans add substantial explanatory power to forecasting regressions. Plans can identify the role of the stock market and corporate profits in determining investment. Because plans are a powerful measure of expected investment, they allow one to decompose actual investment into expected and unexpected components, both at the aggregate and industry level.

At the aggregate level, this decomposition can explain the fact that in post-war US data, investment and stock returns are negatively contemporaneously correlated. The negative correlation of annual investment growth and stock returns is a puzzle because a variety of economic models imply that stock returns and investment should be positively correlated, or at most (if there are investment lags) contemporaneously uncorrelated. With a sufficiently long lag or at sufficiently long horizons, returns and investment are indeed positively correlated. The negative correlation at the annual horizon is surprising because economists typically think of investment and stock returns as being positively correlated. For example Shapiro (1990) begins his discussion of Morck, Shleifer and Vishny (1990) with "The stock market and investment are positively correlated. This well-known empirical finding provides the point of departure for the authors' theoretical discussion."

The plans data provide an explanation for this puzzle, one that is consistent with our existing knowledge about time-varying expected returns. The explanation is that expected stock returns are negatively related to current macroeconomic conditions, but expected investment is 
positively related to current macroeconomic conditions. Thus the expected components of stock returns and investment are negatively correlated.

In contrast, stock returns and innovations to aggregate investment are basically uncorrelated at the annual level. Profits, rather than stock returns, are the primary determinant of revisions to aggregate investment. This result suggests that firms are able to adjust their investment within the year in response to innovations in profits. In this sense, then, at least a part of aggregate investment has investment lags of less than a year.

At the industry level, examination of individual industries' investment plans also shows that current profits are correlated with revisions to investment. Aggregate profits, not industryspecific profits, are the dominant force. This fact suggests that at the industry level, profits are important not because of financial constraints faced by different industries or the signaling power of industry profits, but rather because aggregate profits are correlated with aggregate movement in the desirability of investing in physical capital.

Unlike aggregate investment and aggregate returns, revisions to industry investment and industry returns are positively correlated within the year. Specifically, the estimated coefficients imply that industry investment does not respond to aggregate stock returns, but does respond to industry-specific stock returns (industry returns minus aggregate returns) within the year.

Another feature of plans is that they allow precise measurement of innovations to expectations at relatively high frequencies, illuminating the nature of lags in the investment process. The investment survey asks firms in February how much they expect to spend in the period July-December. Six months later, in August, the survey again asks how much they expect to spend in the period July-December. The difference between these two plans reflects events (such as movements in stock prices) that have occurred between February and August. It turns out that industry-specific stock returns between February and August are positively correlated with these revisions in investment plans.

This paper is organized as follows. Section 2 briefly discusses related research on the relationship between investment and stock returns. Section 3 describes the plans data, defines the variables used, and shows summary statistics. Section 4 shows the basic forecasting ability of plans, and discusses various biases. Section 5 shows results for aggregate investment, aggregate stock returns, and aggregate profits. Section 6 shows industry results, and section 7 presents conclusions. 
2. Current state of our knowledge about the stock market and investment

Traditional $\mathrm{q}$ theory relates investment in current period to beginning-of-period $\mathrm{q}$ (see Chirinko (1993) for a review of this literature). More recently, several papers relate investment to stock returns instead of $\mathrm{q}$, because stock returns perform better in empirical investment equations. Looking at aggregate data, Barro (1990) and Blanchard, Rhee, and Summers (1993) examine the relationship between investment, stock returns, and corporate profits. Both find that both lagged stock returns and contemporaneous profits explain investment, using annual aggregate data for the US. Morck, Shleifer, and Vishny (1990) find similar results for both aggregates and individual companies.

Cochrane (1991) argues that in a world of complete markets (and a simple specification of production technology), returns from investing in a firm and from investing in a capital good should be identical. If the real world is similar to this theoretical world, then investment returns and stock returns should be approximately the same. It turns out that Cochrane's estimate of investment returns (based on a specific functional form for production and investment) is essentially a monotonic function of investment growth. Thus an implication of his approach is that investment growth and stock returns should be positively contemporaneously correlated. Expected investment growth and expected stock returns should also be positively correlated.

Cochrane finds that investment growth and stock returns are indeed positively contemporaneously correlated. However, his results are not directly comparable to those in this paper, because Cochrane uses gross private domestic investment, which includes both residential and nonresidential investment. In contrast, the survey data used here covers only nonresidential investment. Excluding residential investment is standard, since most of the residential capital stock is not traded on equity markets. It turns out that including residential investment substantially increases the correlation of stock returns and investment growth, since residential investment leads nonresidential investment.

\section{Description of the plans data}

\subsection{The survey}

The plant and equipment expenditure survey began in 1947, and over time was administered by various different offices within the Commerce Department. In September 1994 the survey was discontinued. 
The Commerce Department sent quarterly surveys to a sample of corporate and noncorporate firms. Compliance was voluntary. The Commerce Department compiled the survey results into industry and aggregate results. In addition to collecting quarterly investment plans, the survey collected annual plans in a survey that was typically mailed out January and due back in the first week of February. The precise date that the survey results arrived at the Commerce Department varied. According to various issues of the Survey of Current Business, the survey was taken "mid-February" in the late 1940's,"mid-February to mid-March" in the early 1950's, "late January and early March" in late 1950's, "February" in the early 1960's, "late January and February" from 1967 to 1985, and "January and March" in the late 1980's. I treat the survey as representing information as of the last day of February.

In the February survey, firms were asked to state planned investment for the entire year. More precisely, the survey asks respondents to estimate their investment over three periods: QI, QII, and the second half (QIII and QIV) of the year. This paper ignores the quarterly projections and examines only the annual plans (in sections 3,4, and 5) and the plans for the second half of the year (section 6).

The actual wording of the survey is that firms are asked to report "all capital expenditures you expect to make in each of the forthcoming time period shown, whether or not commitments or orders have already been placed" (Green and Hertzberg, 1980). As detailed in the section 4 , the survey responses do not have the mathematical properties of rational expectations. Rather than being unbiased forecasts, Keezer, Ulin, Greenwald, and Matulis (1960) describe similar survey results as representing "varying degrees of finality. Some represent actual construction schedules based on outstanding orders; others, expenditures formally approved by a board of directors."

\subsection{Data definitions}

This paper studies real investment growth in year $t$, defined as nominal investment growth minus inflation for capital goods. Nominal investment growth is $i_{t}=\frac{I_{t}}{I_{t-1}}-1$, where $I_{t}$ is annual 
expenditures on plant and equipment. Planned investment growth is $\hat{i}_{t}=\frac{P_{t}}{I_{t-1}}-1$, where $P_{t}$ indicates the reported level of investment plan.

The Commerce Department survey asks its participants to report their nominal spending on plant and equipment. Real actual investment growth is $g_{t}=\frac{I_{t}}{I_{t-1}}-\frac{D_{t}}{D_{t-1}}$ and real planned growth is $\hat{g}_{t}=\frac{P_{t}}{I_{t-1}}-\frac{D_{t}}{D_{t-1}}$, where $D_{t}$ is the nonresidential fixed investment deflator from the national income accounts. The survey's investment series differs from the nonresidential fixed investment series of the national income accounts due to differences in coverage and data sources. The correlation of annual real investment growth from the survey and from the national income accounts between 1948 and 1993 is 0.87 for real growth and 0.89 for nominal growth (see also Kopcke 1993 for a discussion of this issue). Table 2 briefly examines the effects of deflating investment growth in, but otherwise $\hat{g}_{t}$ is used as if it were the forecast of real investment.

The difference between actual growth and planned growth is $g_{t}-\hat{g}_{t}$, the revision in year $\mathrm{t}$ investment between February and December of year $t$. The inflation adjustment does not affect $g_{t}-\hat{g}_{t}$

Aggregate real stock returns are total returns on the S\&P Composite Index minus CPI inflation. Following Barro, I also use the change in the profits ratio, $\Delta \pi_{t}$, defined as the difference between the ratio of profits to GDP for private industry in year $\mathrm{t}$ and year $\mathrm{t}-1 .^{1} \Delta \pi_{t}$ might help explain investment because it captures the profitability of investment, because it captures the cost of internal funds, or because it captures some other procyclical component of investment behavior.

Table 1 shows summary statistics. First, note that $\sigma\left(g_{\nu}\right)>\sigma\left(\hat{g}_{\nu}\right)$. This variance inequality is a basic property that any good forecast should have. Second, note that $g_{t}$ and $r_{t}$ are negatively

\footnotetext{
${ }^{1}$ Unlike Barro, I use pre-tax profits instead of after-tax profits because pre-tax profits are available both for aggregate and for individual industries.
} 
correlated. This puzzling empirical regularity does not involve plans data. Note also that the correlation of $g_{t}-\hat{g}_{t}$ and $r_{t}$ is much lower. Third, note that $g_{t}-\hat{g}_{t}$ and $\Delta \pi_{t}$ are highly correlated.

Figure 1 shows the time series of $g_{t}$ and $\hat{g}_{t}$. Figure 2 shows revisions in investment, $g_{t}-\hat{g}_{t}$. The recession year of 1982 stands out as a time when actual investment was far below plans as of February. Other recessions also are associated with downward revisions, but of a smaller magnitude. The recessions of 73-75 and 48-49 are particularly noteworthy, since these saw very steep drops in investment which were nevertheless well anticipated by survey respondents.

\section{Regressions of Actual on Planned Investment}

\subsection{Explanatory power}

Columns 1 and 4 of Table 2 show univariate regressions of actual investment growth on planned investment growth. In this subsection I discuss these univariate regressions, and in the next subsection I discuss the multivariate regressions in Table 2.

If plans measure the rational expectation of investment growth, then (1) the intercept in the univariate forecasting regression should be zero, (2) the coefficient should be one, and (3) no other regressor should be significant. Judging from columns 1 and 4 alone, plans do a superb job at satisfying conditions (1) and (2).

However, the excellent forecasting performance in these annual univariate regressions masks substantial bias in the plans at different time horizons. I discuss this issue further in the next subsection.

The explanatory power is quite large. By itself, Table 2's univariate regressions present interesting decompositions of real investment growth: more than three quarters of the variation in investment growth in a given year can be predicted at the beginning of the year.

In interpreting the R-squared, there are several factors to consider. First, it could be that much of investment in a given year is irreversibly determined at the beginning of the year. This fixity makes investment easy to forecast, no matter how uncertain actual events are in the year ahead. Second, it could be that investment within a given year is very flexible, but that the driving forces are easy to forecast. Last, the observed R-squared is a lower bound on the actual predictability of investment growth, since there is undoubtedly measurement error in plans. 
The informativeness of these forecasts appears remarkable, given the generally poor performance of other surveys forecasts over this period. One explanation for this difference in accuracy is that unlike other surveys (for example surveys of inflation expectations), this survey only asks participants to forecast their own behavior, not the behavior of other agents. And most large firms produce such projections for their own internal use (these projections are sometimes made public, e.g. McConnell and Muscarella, 1985).

One piece of evidence in favor of this explanation is that these same firms do not exhibit similar ability at forecasting other variables. During part of the sample period, the Commerce Department survey also asked the firms to forecast price inflation. The resulting inflation forecasts have poor properties (de Leeuw and McKelvey, 1984).

\subsection{Biases in the Plans Data}

The reported plans display systematic forecast errors (de Leeuw and McKelvey (1981)). First, reported plans tend to underestimate actual investment expenditures in the distant future. For example, in the February survey, plans for the second half of the year (from July to December) systematically understate actual investment.

Second, the plans exhibit a systematic seasonal pattern in forecast errors for quarterly data. This seasonal bias causes February's plans for the first half of the year to systematically overstate actual investment. The pattern is consistent with the following behavior of the part of some of the survey respondents: divide intended annual investment by four, and report that as quarterly investment. Since actual investment is generally lowest in the first quarter of the year, plans for the first half of the year systematically overstate actual investment.

The magnitude of these two biases is fairly large, but they roughly cancel out for the annual forecast, resulting in the combined effect that annual plans have a positive forecast error: on average, plans understate actual investment by about $1.4 \%$ during the sample period of 1947 93 (as seen in Table 1). However, the bias diminished over time, falling from about $4 \%$ at the beginning of the sample to about zero at the end. The reduction in bias did not occur because the plans as a whole became more accurate, it occurred because the plans became less accurate in a way that cancelled out. The bias in first-half plans grew worse over time, while the opposite bias in second-half plans stayed constant. The reasons for this trend in bias are unclear, but presumably involve changing seasonal patterns of investment, changing accounting or planning 
practices, changing composition of investment type and firm size, or changing attitudes towards the survey.

These patterns suggests that survey respondents are not trying to forecast investment; instead they are simply reporting their definite program for investment expenditure. Thus the plans variable is perhaps more of an accounting variable than an exact measure of expected investment.

The multivariate regressions in Table 2 reflect the imperfect forecasting properties of investment plans. Due in part to the biases discussed above, revisions to investment are positively autocorrelated (as shown in Table 1). In other words, forecast errors made this year are likely to be inefficiently repeated next year. In Table 2, this autocorrelation of errors appears as a positive coefficient on lagged investment growth and negative coefficient on lagged planned growth. Since the coefficient on lagged planned growth is significant, the multivariate regressions in Table 2 reject the hypothesis that plans are a rational forecast of investment. Quantitatively, however, the added information is small since the R-squared only increases from 0.76 to 0.80 for real investment growth.

The fact that survey participants appear to make systematic errors is not a particular concern for this paper, since I am trying to measure a proxy for expected investment, and am not interested in testing for the rationality of the firms. In this paper, I treat the three variables in column 3 of Table 2, collectively, as a proxy for expected investment.

\subsection{Benchmark Revisions to Expenditure Data}

Like other Commerce Department data, the plant and equipment expenditure survey is routinely revised. Benchmark revisions to incorporate information from census data caused estimates of both actual investment spending and reported planned spending to be revised. In revising the plans, the Commerce Department typically revised the actual spending, then revised the planned spending in order to keep the ratio of actual to plan constant.

In order to ensure that these revisions did not distort the results from Table 2, I reran the regression in column 4 of Table 2 using hand-collected data from the Survey of Current Business, as it was originally published in real-time. The results were very similar. Specifically, using the 38 annual observations on nominal investment growth available from the Survey of Current Business, the R-squared was 0.82, the intercept term was $0.003(0.008)$ and the 
coefficient was $0.99(0.08)$, with a Durbin-Watson statistic of 1.64. This regression used "biasadjusted" planned investment, which reflects adjustments by the Commerce Department that reflect past forecast errors. ${ }^{2}$

\section{Aggregate Investment, Profit, and Stock Returns}

\subsection{Explaining Aggregate Investment}

The first two columns of Table 3 show aggregate regressions of real investment growth on real stock returns and changes in real profits. These regressions are nearly identical to those in Barro (1990) and are also very similar to Blanchard, Rhee, and Summers (1993). I regress $g_{t}$, the real growth in plant and equipment investment, on lagged investment, current and lagged corporate profits, current and lagged real stock returns, and (in columns 3 and 4) current and lagged investment plans.

I focus on the comparison to Barro (1990). Columns 1 and 2, which do not include investment plans, reproduce his results. Column 1 shows that lagged investment, profits, and stock returns all are positively related to current investment. Column 2 shows that current stock returns are negatively correlated with investment, while current profits are positively and significantly related.

What explains the significant negative correlation of contemporaneous stock returns and investment? Similar findings are common in the empirical literature. Barro (1990) finds a negative and significant coefficient on contemporaneous stock returns in a multivariate regression of investment growth in postwar annual data. ${ }^{3}$ In a similar vein, Chen (1991) finds that industrial production is negative correlated with contemporaneous stock returns.

One explanation of this phenomenon lies in a combination of delivery lags and timevarying risk premia on stocks. Expected stock returns rise in recessions and fall in booms (e.g. Fama and French (1989)). Two things happen when we are in a boom this year: stock prices rise today but future expected returns next year fall, and firms plan to increase their investment next year. Thus we observe low average realized stock returns (coming from low expected returns) at

\footnotetext{
${ }^{2}$ The Commerce Department calculates bias-adjustments to account for past forecast errors (and also seasonally adjusts some data). With the exception of this subsection, this paper uses only the raw unadjusted data, since some of the bias-adjustment made on historical data used information that could not have been available in real time.

${ }^{3}$ According to Poterba (1990), current stock returns also have a negative sign in the aggregate regressions of Morck, Shleifer, and Vishny (1990).
} 
the same time that we observe high investment growth. Put differently, actual returns are correlated with expected returns, and expected returns are negatively correlated with expected investment growth. Similarly, Campbell and Mei (1993) explain Chen's industrial production results as reflecting changes in expected future returns.

Column 3 adds plans to the specification in column 1. It shows that plans drive out lagged profits and returns. Lagged profits and returns are individually and jointly insignificant and add very little explanatory power (as the R-squared rises from 0.80 in column 3 of Table 2 to only 0.81 in column 3 of Table 3). Evidently, planned investment in February reflects the information in lagged profits and returns. As in Table 2, the coefficients on lagged planned investment growth and lagged actual investment growth indicate that forecast errors are positively autocorrelated.

Column 4 adds plans to the specification in column 2. Current profits are positively and significantly related to current investment. This result suggests that current profits contain a substantial surprise, and that within a given year, companies are able to increase investment when profits increase. de Leeuw and McKelvey (1981) run similar regressions with the plans data and also find that the unexpected component of profits is positively correlated with investment. The coefficient on current stock returns falls to about zero. This fall supports the time-varying risk premia story: since $\hat{g}_{t}$ measures expected investment, the expected return component of current returns is driven out of the regression. As in column 3 , the coefficients on lagged actual investment growth and lagged planned investment growth reflect positively autocorrelated revisions and the other lagged variables remain insignificant. ${ }^{4}$

Columns 5 and 6 show regressions of where planned growth and revisions (actual minus plan) are the dependent variables. These regressions re-express the relationship in column 4 in different ways. Column 5 puts future variables (reflecting the entire year) in the regression explaining investment plans (which are determined in February). The idea is that this year's investment plans should reflect expectations about next year's profits and stock returns. ${ }^{5}$ Column 5 's results are similar to column 2's, except for the coefficient on current profits (which is now

\footnotetext{
${ }^{4}$ I also tried adding lagged investment to capital ratios, and current and lagged changes in high quality (AAA) long term corporate interest rates, to the specification in Table 4 . These variables were insignificant and did not much affect the other coefficients.

${ }^{5}$ Fama (1990), for example, uses future industrial production to explain current stock returns.
} 
negative and insignificant). The change in the profits ratio in year $t$ appears to contain news not available in February of year $t$.

Column 6 shows that revisions to investment are strongly correlated with contemporaneous profits but are totally unrelated to stock returns. Column 6 introduces a more parsimonious representation of column 4 , by subtracting $\hat{g}_{t}$ from both sides of the equation, and imposing the restriction (not rejected by the data) that the coefficients of $g_{t-1}$ and $\hat{g}_{t-l}$ have equal and opposite signs. I use versions of this regression when examining industry revisions in Tables 6 and 7.

Barro (1990) offers the following interpretation for the results in column 2: "an exogenous disturbance (such as an increase in the prospective rate of return on capital) shows up contemporaneously as an increase in stock prices and corporate profits, and with a lag of a year or more as an expansion on investment expenditures and a further increase in profits." The other columns of Table 3 contradict this interpretation. Current profits are not anticipated in advance but instead surprise firms, and firms are able to immediately (within the year) increase investment in response to an increase in profits. But within the year firms ignore the stock market, given profits.

Table 3 suggests that high planned growth is correlated with low expected returns. This finding suggests that investment plans will be a useful variable in forecasting future stock returns. The next subsection examines this issue.

\subsection{Time-varying risk premia on stocks}

Table 4 shows forecasting regressions for real stock returns. The dependent variable in the first pair of columns is returns from the traditional period of December of year $t-1$ to December of year $\mathrm{t}$.

The first column of Table 4 shows a univariate regression of real annual returns on the S\&P Composite Index on planned investment growth. The result is striking. For every one percent increase in planned investment growth, real returns are more than one percent lower. Since $\hat{g}_{t}$ only reflects information known as of February, the regression implies that $\hat{g}_{t}$ and expected returns are negatively correlated. 
The second column drops plans, and adds more lagged variables that have been shown to forecast returns. It includes lagged returns, lagged dividend yield, lagged dividend payout ratio, lagged term premium, and lagged default premium. Both the dividend yield and the payout ratio correspond to the S\&P Composite (the source of the real return series). The dividend yield is four-quarter dividends divided by price as of December of year $\mathrm{t}-1$. The dividend yield is thought to forecast stock returns because it measures time-varying risk premia on stocks, which are reflected in scaled stock prices. The payout ratio is four-quarter dividends divided by quarterly earnings, as of December of year $t-1$. The dividend payout ratio is advocated by Lamont (1998) as a measure of macroeconomic conditions. The term and default premia variables are based on interest rate spreads and are similar to those used by Fama and French (1989). The term spread is the difference between the long-term Treasury bond yield and the 1month treasury bill rate. The default spread is the difference between the BAA and AAA Corporate bond yields.

The second column shows that these five forecasting variables, in combination, have about as much explanatory power as plans alone. The dividend yield is an important forecasting variable; the other four variables are jointly and individually insignificant.

The third column shows regressions with both plans and the other forecasting variables. One might think that the other variables would have the potential to drive out $\hat{g}_{t}$ from the regression. If $\hat{g}_{t}$ predicts stock returns because it is correlated with Tobin's q, then one would expect other scaled price variables (such as the dividend yield) to absorb some explanatory power. If $\hat{g}_{t}$ predicts stock returns because it is correlated with macroeconomic conditions (as argued in the previous section), then one would expect other macroeconomic variables (such as the dividend payout ratio) to absorb some explanatory power.

It turns out that $\hat{g}_{t}$ is not very highly correlated with the other explanatory variables. Thus the coefficient on $\hat{g}_{t}$ is not dramatically affected by these other variables. Evidently, planned investment contains information about future returns that is not captured by standard variables.

Columns 4 and 5 show similar regressions where the dependent variable is returns from February of year $t$ to February of year $t+1$. These regressions more properly reflect the timing of 
the plans data, which are collected during January and February. The dividend yield, term premium, and default premium are also as of February of year $t$ (since the dividend payout is quarterly, the latest available value in February is still December of year t-1). The results using February data are essentially unchanged.

Table 4 is makes clear why actual investment and returns are negatively correlated. It is because expected investment and expected returns are negatively correlated. This negative correlation is a contradiction of the spirit of Cochrane (1991), who argues that investment growth and stock returns should be positively correlated.

\section{Industry Investment}

The results for aggregate investment suggest that within the year, stock returns have no impact on investment, but profits do. These aggregate results partially reflect movements in aggregate expected stock returns. Thus, one might hope that individual industries would display more of correlation between unexpected stock returns and unexpected investment with the year. Therefore, this section examines results for individual industries. ${ }^{6}$

I study two types of investment plans. The first is the investment plan discussed in the previous part of this paper, annual investment plans made in February for the entire year. The other is "second half" plans, which is planned investment in the period July-December. The Commerce Department collected these second half plans both in February, and six months later in August. Thus instead of comparing plans to actual, one can compare second half plans made in February to second half plans made in August, thus eliminating from the revision the effect of events occurring after August.

\subsection{Summary statistics for industry investment}

Table 5 shows summary statistics for annual and second half plans, for both aggregate and industry data. I collect data on planned and actual investment, profits, and stock returns for the 15 separate industries. I chose these industries since they were both covered by the investment survey, and because annual industry profits and gross domestic product were available from the Commerce Department. Stock return data come from value weighted industry

\footnotetext{
${ }^{6}$ Porter (1997) and Schankerman (1991) present alternate approaches to explaining industry investment.
} 
portfolios constructed using individual firm's stock returns and Standard Industrial Classification codes from the Center for Research in Security Prices (CRSP).

The first two columns of Table 5 show statistics for annual plans. Naturally, the variance of real investment growth for individual industries is much higher than for the aggregate. Air transportation is the most volatile industry, and food is the least volatile. The second column shows the R-squared in a regression of actual real investment growth on planned real investment growth in February (as in column 1 of Table 2). On average, investment growth for individual industries is about as predictable as aggregate investment growth, although the R-squared ranges from 0.38 for fabricated metals to 0.88 for air transportation. Again, predictability could vary for different reasons. It could be that investment in steel mills is inherently less forecastable than in airlines, or it could be that the employees assigned to fill out Commerce Department surveys are less skilled forecasters in steel mills than in airlines.

The rest of Table 5 shows statistics for second half plans. Second half real investment growth is investment in the second half (July through December) of year $t$ divided by second half investment in year t-1: $g_{t}^{2 n d}=\frac{I_{t}^{2 n d}}{I_{t-1}^{2 n d}}-\frac{D_{t}^{2 n d}}{D_{t-1}^{2 n d}}$ and $\hat{g}_{t}^{2 n d}=\frac{P_{t}^{2 n d}}{I_{t-1}^{2 n d}}-\frac{D_{t}^{2 n d}}{D_{t-1}^{2 n d}}$ where the plans, investment, and deflator all come from the second half of the year. The fourth column of Table 5 shows the R-squared in a regression of $g_{t}^{2 n d}$ on $\hat{g}_{i}^{2 n d}$ where the plans are taken from the February survey. The next column shows the same regression with August plans. Not surprisingly, August plans are more accurate than February plans, as the average R-squared increases from 0.47 to 0.79 .

\subsection{Annual revisions to industry investment}

Table 6 examines revisions to annual investment, $g_{t}-\hat{g}_{t}$, pooling together the 15 individual industry series in Table 5 into panel data. It regresses annual revisions on profits and returns, using both industry and aggregate versions of these two variables. In addition to aggregate stock returns and profits from Tables 1 and 3 (which are now denoted $r_{t}^{A G G}$ and $\Delta \pi_{t}^{A G G}$ ), the regression includes real industry stock returns, $r_{t}^{I N D}$, and the change in the ratio of profits to GDP for the individual industry, $\Delta \pi_{t}^{I N D}$. The regressions are analogous to 
column 6 in Table 3 and include lagged revisions. As in Table 3, all the independent variables are annual variables, covering the entire calendar year.

Table 6 shows two versions of the panel data results, both of which account for the cross sectional correlation of the error term within a given year. First, the OLS coefficients are from a fixed-effect specification where each industry has a constant fixed effect, and where the standard errors have been corrected to allow for the residuals to be correlated within years as well as allowing for general heteroskedasticity. Second, the GLS results show generalized least squares estimates of the same fixed-effects specification, allowing for heteroskedasticity with crosssectional correlation.

The first column on Table 6 shows an OLS regression with all five regressors (and with industry-specific intercept terms, not shown). As with aggregate revisions (shown in column 6 of Table 3), industry revisions strongly positively related to aggregate profits. Industry profits and industry returns have positive, but insignificant, coefficients; aggregate returns have a negative but insignificant coefficient. As before, revisions are positively autocorrelated so that lagged revisions come in positive and significant.

For returns, industry and aggregate coefficients have opposite signs and approximately the same magnitude (the data fail to reject the hypothesis that the two coefficients have equal magnitude). The second column of Table 6 shows the effect of imposing the restriction that these two coefficients have the same magnitude, so that the regression has industry returns minus aggregate returns $\left(r_{t}^{I N D}-r_{t}^{A G G}\right)$ on the right hand side. The industry-specific return, $r_{t}^{I N D}-r_{t}^{A G G}$, could also be described as "abnormal return" and is approximately the same variable used by Morck, Shleifer, and Vishny (1990) to examine capital expenditures by individual firms.

Morck, Shleifer, and Vishny's (1990) variable was returns in excess of the return predicted by the CAPM, which approximately equals firm returns minus aggregate returns (since the average CAPM beta equals one). They regressed three year investment growth (from year $t$ to year $\mathrm{t}+3$ ) on lagged abnormal returns (from year $\mathrm{t}-1$ to $\mathrm{t}+2$ ) for individual firms, and included several other control variables. They found that high return firms did have higher investment (with a coefficient of around 0.3 on excess returns), although they argued that the small incremental explanatory power of stock returns indicated a minor role for stock returns. 
Columns 3-7 use OLS regressions to explore the different variables' contribution to explanatory power. For example, column 3 shows that lagged revisions and the industry-specific dummy variables explain twenty percent of the variance of revisions. Column 2 shows that for explaining industry revisions, the most important variable by far is aggregate profits. By themselves (in column 5) industry profits have a larger and significant coefficient, but together with aggregate profits (in columns 1 and 2) the coefficient shrinks and becomes insignificant. Aggregate profits always have a large and highly significant coefficient.

Columns 8 and 9 show GLS versions of columns 1 and 2 . In these regressions, returns (either separately or as $r_{t}^{I N D}-r_{t}^{A G G}$ ) are significant, and industry-specific returns are positively related to industry investment revisions. The coefficient in column 9 implies that an industryspecific return of $15 \%$ (which is the standard deviation of $r_{t}^{I N D}-r_{t}^{A G G}$ ) revises investment growth up by more than one percent.

\subsection{Second-half revisions to industry investment}

Table 7 shows regressions explaining second half revisions to plans. It regresses revisions in investment plans between February and August, $\hat{g}_{t, A U G}^{2 n d}-\hat{g}_{t, F E B}^{2 n d}$, on real stock returns between February and August, as well as on profits and lagged revisions. The dependent variable, $\hat{g}_{t, A U G}^{2 n d}-\hat{g}_{t, F E B}^{2 \text { nd }}$, can not be affected by unexpected events occuring after August. In principal it should reflect not events occuring before February (although in fact it does, due to the autocorrelation of forecast errors).

Revisions to second half plans offer a more precise way of examining the effect of returns on investment while allowing for some lag between observed events and investment behavior. If there are lags between the decision to invest and the actual investment expenditure, Table 7 will be better than Table 6 at detecting connections between returns and investment. Table 6 examines only contemporanous annual correlations between returns and investment revisions, while Table 7 allows for a lag between events and the investment expenditure. The specification allows for lags between stock returns and actual investment because the plans concern investment in the second half of the year, July to December. 
$\hat{g}_{t, A U G}^{2 n d}-\hat{g}_{t, F E B}^{2 n d}$ should reflect only information that occurs between February and August. Since we observe stock prices in both February and August, and since stock returns are largely unpredictable, Table 7 measures the correlation between innovations to investment plans and innovations to returns. Unfortunately, industry profits are only available annually, so we observe innovations to profits much less precisely. Table 7's regressions include as independent variables the annual change in profit ratios at the aggregate and industry level, the same variables that appear in Table 6.

In general, the results in Table 7 are similar to, but stronger than, the results in Table 6. For returns, the coefficients are higher and are significant in both columns 1-2 and 8-9. Column 9 shows the effect of an innovation in industry-specific returns is three times as high as in Table 6. The coefficients imply that that an $r_{t, F E B-A U G}^{I N D}-r_{t, F E B-A U G}^{A G G}$ of $9 \%$ (its standard deviation) revises investment growth up by more than two percent.

For profits, aggregate profits continue to have a large and significant coefficient. Industry profits have a coefficient that is statistically significant for the GLS results. In terms of explanatory power, aggregate profits are most important.

To summarize, Tables 6 and 7 show that innovations to industry investment have a positive relation with industry-specific stock returns within the year. Aggregate profits are highly correlated with revisions to industry investment. Industry-specific profits have a weaker affect on revisions to investment, but one that is statistically detectable using the more powerful GLS regressions in Table 7. Tables 6 and 7 show that investment lags must be less than ten months, at least for part of investment, since new information arriving between February and August affects second half investment plans.

The relatively small amount of explanatory power on industry-specific profits compared to aggregate profits suggests that profits are not correlated with investment at the industry level due to financial constraints, but rather because aggregate profits measure some non-financial macroeconomic variation in investment behavior. Of course, since these results only pertain to the industry level of aggregation, they do not contradict the voluminous evidence on cash flow and investment at the firm level. For a review of the literature on financial constraints and investment, see Hubbard (1998). 


\section{Conclusions}

A substantial amount of the variation in investment in a given year can be forecast at the beginning of the year, suggesting that expected investment growth is a large part of actual investment growth. At the aggregate level, the remaining unexpected component of investment is strongly positively related to profits, and unrelated to current stock returns.

The traditional explanation for the absence of a relationship between stock returns and investment within the year is that delivery lags, planning lags, and construction lags make a year too short a time to observe a reaction. The presence of contemporaneous profits in aggregate investment regressions has been reconciled with this explanation by hypothesizing that profits are predictable in advance. This explanation is now less credible, since aggregate profits appear to contain a substantial surprise, and firms are able to react to this surprise within the year. For some reason, then, aggregate investment reacts faster to profits than to stock returns. In addition, plans show that the negative correlation between current stock returns and current investment is primarily caused by a negative correlation between expected investment and expected returns.

At the industry level, industry-specific stock returns do affect investment within the year. When both industry stock returns and aggregate returns move up together, investment within the year does not react. When industry-specific returns go up, investment plans are revised upward within the year. In profits, the pattern is reversed. Industry investment reacts much more strongly to aggregate profits than to industry-specific profits, suggesting that an important reason that profitability is correlated with investment is that aggregate profitability captures unexpected shocks that are common to all industries. 


\section{REFERENCES}

Barro, Robert J., "The Stock Market and Investment," Review of Financial Studies, Vol 3 No 1, 1990, 151-131.

Blanchard, Olivier, Changyong Rhee, and Lawrence Summers, "The Stock Market, Profit, and Investment," Quarterly Journal of Economics, February 1993, Vol CVIII, Issue 1, 77-114.

Campbell, John Y., and Jianping Mei, 1993, Where do betas come from? Asset price dynamics and the sources of systematic risk, Review of Financial Studies 6, 567-592.

Chen, Nai-Fu, 1991, Financial investment opportunities and the macroeconomy, Journal of Finance 46,529-554.

Chirinko, Robert S., Business Fixed Investment Spending: Modeling Strategies, Empirical Results, and Policy Implications, Journal of Economic Literature, Vol. XXXI (December 1993), pp. $1875-1911$.

Cochrane, John H., "Production-Based Asset Pricing and the Link Between Stock Returns and Economic Fluctuations," Journal of Finance, 1991, Vol. XLVI, No. 1, pp. 209-237.

de Leeuw, Frank, and Michael J. McKelvey, 1981, The realization of plans reported in the BEA plant and equipment survey, Survey of Current Business, October 61(10), 28-37.

de Leeuw, Frank, and Michael J. McKelvey, 1984, Price Expectations of Business Firms: Bias in the Short and Long Run, American Economic Review; v74 n1 March 1984, pp. 99-110.

Fama, Eugene F. and Kenneth R. French, 1989, Business conditions and expected returns on stocks and bonds, Journal of Financial Economics 25, 23-49.

Fama, Eugene F., 1990, Stock returns, expected returns, and real activity, Journal of Finance 45, 1089-1108.

Green, George R. and Marie P. Hertzberg, 1980, Revised estimates of new plant and equipment expenditures in the United States, 1947-77, Survey of Current Business, October 60(10), 24-59.

Hubbard, R.Glenn, 1998, Capital-market imperfections and investment, Journal of Economic Literature 36, 193-225.

Keezer, Dexter M., Robert P. Ulin, Douglas Greenwald, and Margaret Matulis, 1960, "Observations of the Predictive Quality of McGraw-Hill Surveys of Business' Plans for New Plants and Equipment," in National Bureau of Economic Research, The Quality and Economic Significance of Anticipations Data, Princeton University Press. 
Kopcke, Richard W., 1993, Forecasting Investment with Models and Surveys of Capital Spending, New England Economic Review, March/April 49-69.

Lamont, Owen, 1998, Earnings and expected returns, Journal of Finance 53, 1563-1587.

McConnell, John J., Chris J. Muscarella, 1985, Corporate Capital Expenditure Decisions and the Market Value of the Firm, Journal of Financial Economics, v14 n3, pp. 399-422.

Morck, Randall, Andrei Shleifer, Robert W. Vishny, 1990, The stock market and investment: Is the market a sideshow?, Brookings Paper on Economic Activity, 2:1990, 157-202.

Poterba, James M., Comment on Morck, Shleifer, Vishny, Brookings Paper on Economic Activity, 2:1990, 208-215.

Porter, Robert B., Time-to-plan and the equivalence of expected equity return and expected investment return, working paper, 1997.

Schankerman, Mark, 1991, Revisions of investment plans and the stock market rate of return, NBER working paper 3937.

Shapiro, Matthew, Comment on Morck, Shleifer, Vishny, Brookings Paper on Economic Activity, 2:1990, 203-208. 
Table 1

Summary Statistics, 1948-1993

Descriptive statisitics for real investment growth (actual and planned), real stock returns, and profits. $g_{t}=\frac{I_{t}}{I_{t-1}}-\frac{D_{t}}{D_{t-1}}$ is actual real investment growth and $\hat{g}_{t}=\frac{P_{t}}{I_{t-1}}-\frac{D_{t}}{D_{t-1}}$ is planned real investment growth, where $I_{t}$ is actual annual expenditures on plant and equipment from the Commerce Department survey, $\mathrm{D}_{\mathrm{t}}$ is the nonresidential fixed investment deflator from the national income accounts, and $\mathrm{P}_{\mathrm{t}}$ is planned investment in year $\mathrm{t}$ as of the Commerce Department survey in February of year $\mathrm{t}$. The revision, $\mathrm{g}_{\mathrm{t}}-\hat{\mathrm{g}}_{\mathrm{t}}$, is the difference between actual investment growth and planned investment growth as of February of year t. $\Delta \pi_{\mathrm{t}}$ is the change in the ratio of pre-tax profits to GDP of private industry. $r_{t}$ is real stock returns, the total return on the $S \& P$ Composite Index between the end of December in year $t-1$ and the end of December in year $t$, minus the percent change in the Consumer Price Index between inflation between the end of December in year $\mathrm{t}-1$ and the end of December in year $\mathrm{t}$.

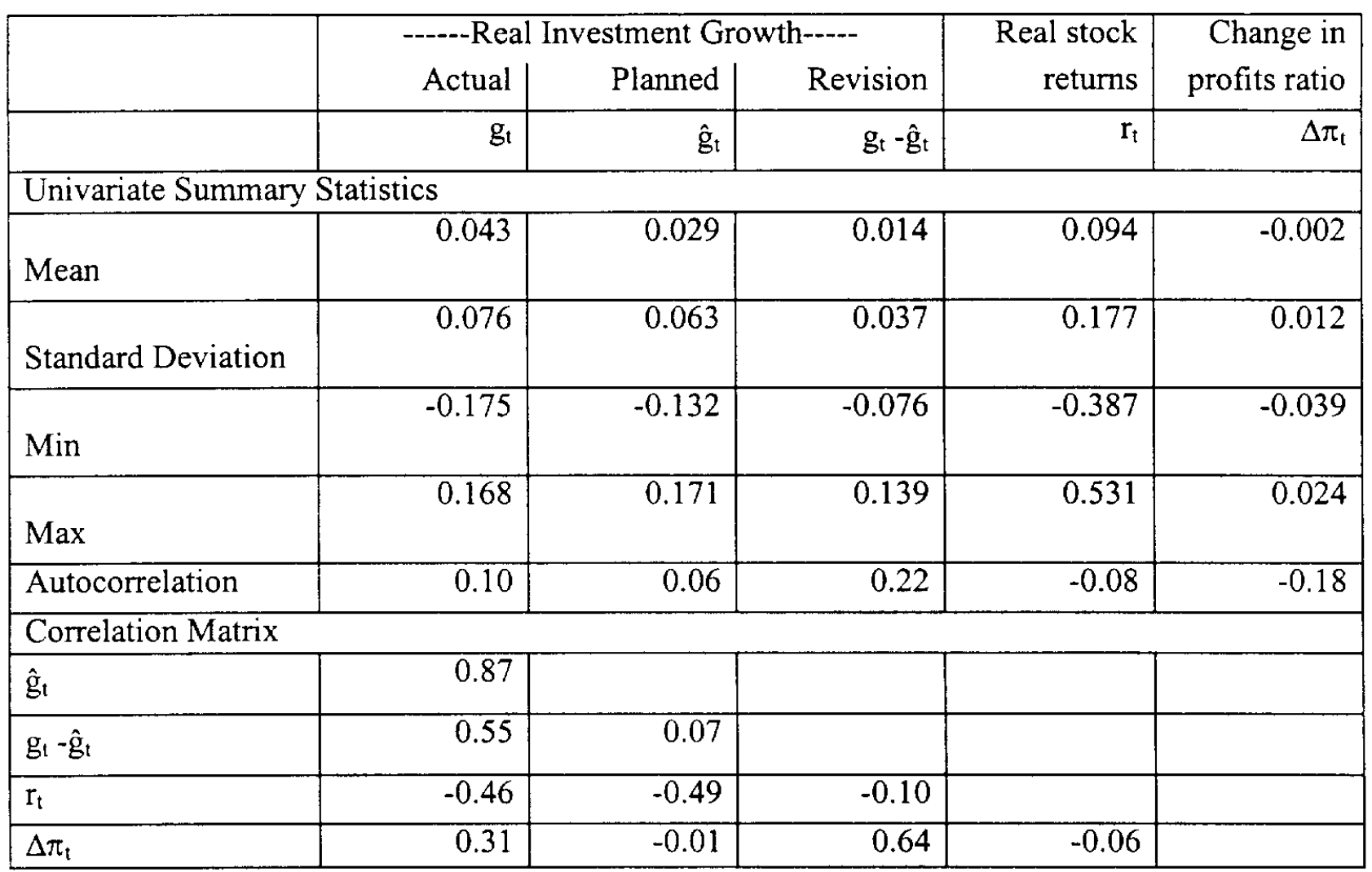


Table 2

Forecasting Properties of Investment Plans, 1948-1993

OLS regressions of actual investment growth on planned growth. Standard errors in parentheses. $g_{t}=\frac{I_{t}}{I_{t-1}}-\frac{D_{t}}{D_{t-1}}$ is real investment growth, $\hat{g}_{t}=\frac{P_{t}}{I_{t-1}}-\frac{D_{t}}{D_{t-1}}$ is planned real investment growth, $i_{t}=\frac{I_{t}}{I_{t-1}}-1$ is nominal investment growth, and $\hat{i}_{t}=\frac{P_{t}}{I_{t-1}}-1$ is planned nominal investment growth, where $I_{t}$ is annual expenditures on plant and equipment from the Commerce Department survey, $D_{t}$ is the nonresidential fixed investment deflator from the National Income and Product Accounts, and $\mathrm{P}_{\mathrm{t}}$ is planned investment in year $\mathrm{t}$ as of the Commerce Department survey in February of year $t$

\begin{tabular}{|l|l|l|l|l|l|l|l|}
\hline \multicolumn{9}{|c|}{ Real } & \multicolumn{4}{c|}{ Nominal } \\
\hline & \multicolumn{2}{|c|}{ Dependent variable: $\mathrm{g}_{\mathrm{t}}$} & \multicolumn{4}{|c|}{ Dependent variable: $\mathrm{i}_{\mathrm{t}}$} \\
\hline & 1 & 2 & 3 & & 4 & 5 & \multicolumn{1}{|c|}{6} \\
\hline Constant & 0.01 & 0.02 & 0.02 & Constant & 0.01 & 0.03 & 0.03 \\
\hline & $(0.01)$ & $(0.01)$ & $(0.01)$ & & $(0.01)$ & $(0.01)$ & $(0.01)$ \\
\hline $\mathrm{g}_{\mathrm{t}}$ & 1.04 & 1.05 & 1.01 & $\hat{\mathrm{i}}_{\mathrm{t}}$ & 1.01 & 1.02 & 0.96 \\
\hline & $(0.09)$ & $(0.09)$ & $(0.09)$ & & $(0.08)$ & $(0.07)$ & $(0.08)$ \\
\hline$\hat{\mathrm{g}}_{\mathrm{t}-1}$ & & -0.19 & -0.44 & $\hat{\mathrm{t}}_{\mathrm{t}-1}$ & & -0.20 & -0.48 \\
\hline & & $(0.09)$ & $(0.18)$ & & & $(0.07)$ & $(0.17)$ \\
\hline $\mathrm{g}_{\mathrm{t}-1}$ & & & 0.24 & $\mathrm{i}_{\mathrm{t}-1}$ & & & 0.27 \\
\hline & & & $(0.15)$ & & & & $(0.16)$ \\
\hline & & & & & & & \\
\hline R2 & 0.76 & 0.78 & 0.80 & $\mathrm{R} 2$ & 0.80 & 0.83 & 0.84 \\
\hline No. of obs & 46 & 45 & 45 & No. of obs & 46 & 45 & 45 \\
\hline DW & 1.55 & 1.56 & 2.14 & DW & 1.55 & 1.59 & 2.23 \\
\hline
\end{tabular}


Table 3

Explaining Actual and Planned Investment Growth, 1949-1993

OLS regressions explaining actual investment growth, planned investment growth, and revisions to plans. $g_{t}$ is real investment growth, $\hat{g}_{t}$ is planned real investment growth in year $t$ as of February of year $t$, and $g_{t}-\hat{g}_{t}$ is the revision (the difference between actual and planned investment growth). $\Delta \pi_{t}$ is the change in the ratio of pre-tax profits to GDP of private industry. $r_{t}$ is real returns between December of year $t-1$ and December of year $t$ (the total return on the S\&P Composite minus annual CPI inflation). $\mathrm{N}=45$ annual observations. Standard errors in parentheses.

\begin{tabular}{|c|c|c|c|c|c|c|}
\hline \multirow{2}{*}{$\begin{array}{l}\text { Dependent } \\
\text { Variable: }\end{array}$} & \multicolumn{4}{|c|}{ Actual investment: $g_{t}$} & \multirow{2}{*}{$\begin{array}{c}\text { Plans: } \hat{g}_{t} \\
5\end{array}$} & \multirow{2}{*}{$\frac{\text { Revisions: } g_{t}-\hat{g}_{t}}{6}$} \\
\hline & 1 & 2 & 3 & 4 & & \\
\hline Constant & $\begin{array}{l}0.02 \\
(0.01)\end{array}$ & $\begin{array}{l}0.03 \\
(0.01)\end{array}$ & $\begin{array}{l}0.01 \\
(0.01)\end{array}$ & $\begin{array}{l}0.01 \\
(0.01)\end{array}$ & $\begin{array}{l}0.02 \\
(0.01)\end{array}$ & $\begin{array}{l}0.01 \\
(0.00)\end{array}$ \\
\hline$g_{t-1}$ & $\begin{array}{l}0.20 \\
(0.14)\end{array}$ & $\begin{array}{l}0.34 \\
(0.12)\end{array}$ & $\begin{array}{l}0.37 \\
(0.19)\end{array}$ & $\begin{array}{l}0.66 \\
(0.12)\end{array}$ & $\begin{array}{l}-0.01 \\
(0.23)\end{array}$ & \\
\hline$r_{t}$ & & $\begin{array}{l}-0.12 \\
(0.04)\end{array}$ & & $\begin{array}{l}-0.02 \\
(0.02)\end{array}$ & $\begin{array}{l}-0.12 \\
(0.04)\end{array}$ & $\begin{array}{l}-0.01 \\
(0.02)\end{array}$ \\
\hline $\mathrm{r}_{\mathrm{t}-1}$ & $\begin{array}{l}0.22 \\
(0.06)\end{array}$ & $\begin{array}{l}0.17 \\
(0.05)\end{array}$ & $\begin{array}{l}0.03 \\
(0.04)\end{array}$ & $\begin{array}{l}0.01 \\
(0.03)\end{array}$ & $\begin{array}{l}0.16 \\
(0.04)\end{array}$ & $\begin{array}{l}-0.01 \\
(0.02)\end{array}$ \\
\hline$\Delta \pi_{\mathrm{t}}$ & & $\begin{array}{l}2.67 \\
(0.74)\end{array}$ & & $\begin{array}{l}2.73 \\
(0.38)\end{array}$ & $\begin{array}{l}0.03 \\
(0.68)\end{array}$ & $\begin{array}{l}2.70 \\
(0.34)\end{array}$ \\
\hline$\Delta \pi_{t-1}$ & $\begin{array}{l}3.10 \\
(0.79)\end{array}$ & $\begin{array}{l}2.99 \\
(0.63)\end{array}$ & $\begin{array}{l}-0.59 \\
(0.74)\end{array}$ & $\begin{array}{l}-0.51 \\
(0.48)\end{array}$ & $\begin{array}{l}3.02 \\
(0.72)\end{array}$ & $\begin{array}{l}-0.71 \\
(0.39)\end{array}$ \\
\hline$\hat{\mathrm{g}}_{\mathrm{t}}$ & & & $\begin{array}{l}1.01 \\
(0.12)\end{array}$ & $\begin{array}{l}0.94 \\
(0.09)\end{array}$ & & \\
\hline$\hat{\mathrm{g}}_{\mathrm{t}-1}$ & & & $\begin{array}{l}-0.53 \\
(0.22)\end{array}$ & $\begin{array}{l}-0.63 \\
(0.14)\end{array}$ & $\begin{array}{l}0.25 \\
(0.26)\end{array}$ & \\
\hline $\mathrm{g}_{\mathrm{t}-1}-\hat{\mathrm{g}}_{\mathrm{t}-1}$ & & & & & & $\begin{array}{l}0.66 \\
(0.13)\end{array}$ \\
\hline $\mathrm{R} 2$ & 0.47 & 0.68 & 0.81 & 0.92 & 0.63 & 0.67 \\
\hline D-W & 1.82 & 1.58 & 2.01 & 2.17 & 1.39 & 2.15 \\
\hline
\end{tabular}


Table 4

Forecasting Stock Returns with Investment Plans, 1948-1993

OLS regressions predicting stock returns using plans and other lagged variables. December-toDecember variables: the dependent variable is real S\&P Composite stock returns between the end of December of year $t-1$ and the end of December of year $t ; \hat{g}_{t}$ is planned real investment growth in year $t$ as of February of year $t$; Dividend yield $\mathrm{d}_{\mathrm{t}-1}$ is the S\&P Composite dividend yield as of December of year $\mathrm{t}-1$; Dividend payout $\mathrm{t}_{\mathrm{t}-1}$ is the $\mathrm{S} \& \mathrm{P}$ Composite dividend payout ratio (ratio of four-quarter dividends to quarterly earnings) as of the end of December of year $\mathrm{t}-1$; Term premium $_{\mathrm{t}-1}$ is the yield on AAA Corporates minus the 3-month Treasury bill yield as of December of year t-1; Default premium $\mathrm{t}_{\mathrm{t}-1}$ is the yield on BAA Corporates minus the yield on AAA Corporates as of December of year t-1. February-to-February variables: the dependent variable is real $S \& P$ Composite stock returns between the end of February of year $t$ and the end of February of year $\mathrm{t}+1$; the lagged return, dividend yield, term premium, and default premium are all as of the end of February of year $t$; the dividend payout ratio (which is only available quarterly) remains as of December of year $\mathrm{t}-1 . \mathrm{N}=46$ annual observations. Standard errors in parentheses.

\begin{tabular}{|c|c|c|c|c|c|}
\hline & \multicolumn{3}{|c|}{$\begin{array}{c}\text { December-to-December } \\
\text { Returns }\end{array}$} & \multicolumn{2}{|c|}{$\begin{array}{c}\text { February-to-February } \\
\text { Returns }\end{array}$} \\
\hline & 1 & 2 & 3 & 4 & 5 \\
\hline Constant & $\begin{array}{l}0.13 \\
(0.02)\end{array}$ & $\begin{array}{l}-0.38 \\
(0.16)\end{array}$ & $\begin{array}{l}-0.18 \\
(0.17)\end{array}$ & $\begin{array}{l}0.45 \\
(0.02)\end{array}$ & $\begin{array}{l}-0.19 \\
(0.15)\end{array}$ \\
\hline$\hat{\mathrm{g}}_{\mathrm{t}}$ & $\begin{array}{l}-1.36 \\
(0.37)\end{array}$ & & $\begin{array}{l}-1.13 \\
(0.41)\end{array}$ & $\begin{array}{l}-1.10 \\
(0.32)\end{array}$ & $\begin{array}{l}-0.82 \\
(0.33)\end{array}$ \\
\hline $\mathrm{r}_{\mathrm{t}-1}$ & & $\begin{array}{l}-0.05 \\
(0.14)\end{array}$ & $\begin{array}{l}0.05 \\
(0.14)\end{array}$ & & $\begin{array}{l}0.06 \\
(0.13)\end{array}$ \\
\hline Dividend yield $_{t-1}$ & & $\begin{array}{l}7.24 \\
(2.28)\end{array}$ & $\begin{array}{l}5.03 \\
(2.26)\end{array}$ & & $\begin{array}{l}5.56 \\
(1.97)\end{array}$ \\
\hline Dividend payout $_{t-1}$ & & $\begin{array}{l}0.06 \\
(0.05)\end{array}$ & $\begin{array}{l}0.03 \\
(0.05)\end{array}$ & & $\begin{array}{l}0.03 \\
(0.04)\end{array}$ \\
\hline Term premium pr-1 & & $\begin{array}{l}0.02 \\
(0.02)\end{array}$ & $\begin{array}{l}0.03 \\
(0.02)\end{array}$ & & $\begin{array}{l}0.02 \\
(0.02)\end{array}$ \\
\hline Default premium $t-1$ & & $\begin{array}{l}0.01 \\
(0.01)\end{array}$ & $\begin{array}{l}-0.01 \\
(0.05)\end{array}$ & & $\begin{array}{l}-0.03 \\
(0.05)\end{array}$ \\
\hline $\mathrm{R} 2$ & 0.24 & 0.25 & 0.37 & 0.21 & 0.37 \\
\hline
\end{tabular}


Table 5

Summary Statistics For Real Investment Growth By Industry, Annual and Second Half

\begin{tabular}{|c|c|c|c|c|c|}
\hline & \multicolumn{2}{|c|}{ Annual } & \multicolumn{3}{|c|}{ Second Half } \\
\hline & $\sigma\left(g_{t}\right)$ & $\mathrm{R} 2$ & $\sigma\left(g_{t}^{2 n d}\right)$ & $\begin{array}{l}\text { R2 on February } \\
\text { Plan }\left(\hat{g}_{t, F E B}^{2 n d}\right)\end{array}$ & $\begin{array}{l}\mathrm{R} 2 \text { on August } \\
\text { Plan }\left(\hat{g}_{i, A U G}^{2 \text { nd }}\right)\end{array}$ \\
\hline All Industries & 0.08 & 0.76 & 0.08 & $\overline{0.42}$ & 0.90 \\
\hline 1. Stone Clay and Glass & 0.21 & 0.70 & 0.27 & 0.49 & 0.78 \\
\hline 2. Primary Metals & 0.25 & 0.87 & 0.28 & 0.72 & 0.89 \\
\hline 3. Fabricated Metals & 0.13 & 0.38 & 0.15 & 0.17 & 0.62 \\
\hline 4. Electrical Machinery & 0.19 & 0.72 & $\overline{0.20}$ & 0.62 & 0.87 \\
\hline 5. Machinery Except Electrical & 0.17 & 0.42 & 0.20 & 0.17 & 0.72 \\
\hline 6. Motor Vehicles & 0.23 & 0.72 & 0.23 & 0.50 & 0.76 \\
\hline 7. Food Including Beverage & 0.09 & 0.46 & 0.10 & 0.21 & 0.61 \\
\hline 8. Textiles & 0.18 & 0.76 & 0.21 & 0.46 & 0.85 \\
\hline 9. Paper & 0.19 & 0.80 & 0.20 & 0.69 & 0.84 \\
\hline 10. Chemicals & 0.17 & 0.79 & 0.18 & 0.68 & 0.79 \\
\hline 11. Petroleum & 0.14 & 0.66 & 0.15 & 0.42 & 0.74 \\
\hline 12. Rubber & 0.21 & 0.75 & 0.26 & 0.62 & 0.87 \\
\hline 13. Railroad Transportation & 0.17 & 0.62 & 0.21 & 0.30 & 0.83 \\
\hline 13. Air Transportation & 0.37 & 0.88 & 0.41 & 0.73 & 0.93 \\
\hline 15. Mining & 0.13 & 0.53 & 0.14 & 0.24 & 0.73 \\
\hline Average of 15 industries & 0.19 & 0.67 & 0.21 & 0.47 & 0.79 \\
\hline
\end{tabular}




\section{Notes to Table 5}

Descriptive statistics for aggregate investment and for 15 individual industries. $\sigma\left(g_{t}\right)$ is the standard deviation of industry $g_{t}$, real annual investment growth. Annual $\mathrm{R} 2$ shows the results from a regression of actual annual investment growth on planned annual investment growth as of February (a regression of $\mathrm{g}_{\mathrm{t}}$ on $\hat{\mathrm{g}}_{\mathrm{t}}$ ). Second half plans are defined as $g_{t}^{2 n d}=\frac{I_{t}^{2 n d}}{I_{t-1}^{2 n d}}-\frac{D_{t}^{2 n d}}{D_{t-1}^{2 n d}}$ and $\hat{g}_{t}^{2 n d}=\frac{P_{t}^{2 n d}}{I_{t-1}^{2 n d}}-\frac{D_{t}^{2 n d}}{D_{t-1}^{2 n d}}$ where the plans, investment, and deflator all refer to the second half of the year (July-December). None of the variables are seasonally adjusted. $\sigma\left(g_{t}^{2 n d}\right)$ is the standard deviation of industry $g_{t}$, the real investment growth from the second half of year $t-1$ to the second half of year t. "R2 on Feb. plan" is the R-squared from a regression of actual second half investment growth on planned second half investment growth as of the end of February of year $t$. "R2 on Aug. plan" is the R-squared from a regression of actual second half investment growth on planned second half investment growth as of the end of August of year t. "All industries" is the total over all firms in the survey, not just from the 15 industries shown here, and corresponds to the aggregate data used in Tables 1-4. The sample period is 1948-1993 $(\mathrm{N}=46)$ for all industries, railroad transportation, and mining, and 1952-1993 $(\mathrm{N}=42)$ for the other industries. Standard errors in parentheses 
Table 6

Panel data: Revisions to annual real industry investment growth, $g_{t}-\hat{g}_{t}$

Multivariate regressions of annual revisions on industry and aggregate returns and profits. Panel data using 15 individual industries. The dependent variable is $g_{t}-\hat{g}_{t}$, the difference between actual annual investment growth and planned annual investment growth as of February of year $t$. $r_{t}^{I N D}$ is real industry stock returns, total returns on a value weighted portfolio of all CRSP firms in the industry minus annual CPI inflation, between December of year $\mathrm{t}-1$ and December of year $\mathrm{t}$. $\Delta \pi_{t}^{I N D}$ is the change in the annual ratio of pre-tax profits to GDP for the relevant industry. $r_{t}^{A G G}$ and $\Delta \pi_{t}^{A G G}$ are aggregate real stock returns and the aggregate real change in the profits ratio, the same variables used in Table 3. The OLS regressions use an unbalanced panel of the 15 industries $(\mathrm{N}=627)$. The GLS regressions use a balanced panel with the sample period 19531993 for the 15 industries $(\mathrm{N}=615)$. All regressions include a constant term and 14 individual industry dummy variables, not shown. The OLS standard errors have been corrected to allow for both heteroskedasticity and cross-sectional correlation within years. The GLS estimates allow for both heteroskedasticity and cross-sectional correlation within years.

\begin{tabular}{|c|c|c|c|c|c|c|c|c|c|}
\hline & \multicolumn{7}{|c|}{ OLS } & \multicolumn{2}{|c|}{ GLS } \\
\hline & 1 & 2 & 3 & 4 & 5 & 6 & 7 & 8 & 9 \\
\hline$r^{I N D}$ & 0.03 & & & 0.01 & & & & 0.08 & \\
\hline & $(0.02)$ & & & $(0.02)$ & & & & $(0.02)$ & \\
\hline$\Delta \pi^{I N D}$ & 0.10 & 0.10 & & & 0.28 & & & 0.05 & 0.06 \\
\hline & $(0.06)$ & $(0.06)$ & & & $(0.07)$ & & & $(0.04)$ & $(0.04)$ \\
\hline$r_{t}^{A G G}$ & -0.05 & & & & & -0.03 & & -0.10 & \\
\hline & $(0.04)$ & & & & & $(0.04)$ & & $(0.03)$ & \\
\hline$\Delta \pi_{i}^{A G G}$ & 3.08 & 3.11 & & & & & 3.40 & 2.34 & 2.38 \\
\hline & $(0.63)$ & $(0.61)$ & & & & & $(0.58)$ & $(0.54)$ & $(0.53)$ \\
\hline$r_{1}^{I N D}-r_{1}^{A G G}$ & & 0.03 & & & & & & & 0.08 \\
\hline & & $(0.02)$ & & & & & & & $(0.02)$ \\
\hline$g_{t-1}-\hat{g}_{t-1}$ & 0.29 & 0.30 & 0.23 & 0.23 & 0.26 & 0.23 & 0.29 & 0.26 & 0.26 \\
\hline & $(0.04)$ & $(0.04)$ & $(0.05)$ & $(0.04)$ & $(0.04)$ & $(0.05)$ & $(0.04)$ & $(0.04)$ & $(0.04)$ \\
\hline $\mathrm{R} 2$ & 0.30 & 0.30 & 0.20 & 0.20 & 0.23 & 0.20 & 0.29 & & \\
\hline
\end{tabular}


Table 7

Industry data: February to August revision in planned $2^{\text {nd }}$ half investment, $\hat{g}_{t, A U G}^{2 n d}-\hat{g}_{t, F E B}^{2 n d}$

Multivariate regressions of revisions to planned second half investment on industry and aggregate returns and profits . Panel data using 15 individual industries. The dependent variable is $\hat{g}_{t, A U G}^{2 n d}-\hat{g}_{t, F E B}^{2 n d}$, the difference between planned second half investment growth as of August of year $t$ and planned second half investment growth as of February of year t. $r_{t, F E B-A U G}^{I N D}$ is real industry stock returns (total returns on a value weighted portfolio of all CRSP firms in the industry minus CPI inflation) between February of year $\mathrm{t}$ and August of year t. $\Delta \pi_{t}^{I N D}$ is the change in the annual ratio of pre-tax profits to GDP for the relevant industry. $r_{t, F E B-A U G}^{A G G}$ is real aggregate stock returns (total returns on the S\&P Composite minus CPI inflation, between February of year $t$ and August of year $t$ ) between February of year $t$ and August of year $t$. $\Delta \pi_{t}^{A G G}$ is the change in the annual ratio of pre-tax profits to GDP of all private industry. None of the variables are seasonally adjusted. The OLS regressions use an unbalanced panel of the 15 industries $(\mathrm{N}=627)$. The GLS regressions use a balanced panel with the sample period 19531993 for the 15 industries $(\mathrm{N}=615)$. All regressions include a constant term and 14 individual industry dummy variables, not shown. The OLS standard errors have been corrected to allow for both heteroskedasticity and cross-sectional correlation within years. The GLS estimates allow for both heteroskedasticity and cross-sectional correlation within years.

\begin{tabular}{|c|c|c|c|c|c|c|c|c|c|}
\hline & \multicolumn{7}{|c|}{ OLS } & \multicolumn{2}{|c|}{ GLS } \\
\hline & 1 & 2 & 3 & 4 & 5 & 6 & 7 & 8 & 9 \\
\hline$r_{t, F E B-A U G}^{I N D}$ & $\begin{array}{r}0.22 \\
(0.05)\end{array}$ & & & $\begin{array}{r}0.09 \\
(0.05)\end{array}$ & & & & $\begin{array}{r}0.24 \\
(0.04)\end{array}$ & \\
\hline$\Delta \pi_{t}^{I N D}$ & $\begin{array}{r}0.13 \\
(0.08)\end{array}$ & $\begin{array}{r}0.14 \\
(0.08)\end{array}$ & & & $\begin{array}{r}0.43 \\
(0.09)\end{array}$ & & & $\begin{array}{r}0.12 \\
(0.04)\end{array}$ & $\begin{array}{r}0.11 \\
(0.04)\end{array}$ \\
\hline$r_{t, F E B-A U G}^{A G G}$ & $\begin{array}{r}-0.26 \\
(0.07)\end{array}$ & & & & & $\begin{array}{r}-0.02 \\
(0.07)\end{array}$ & & $\begin{array}{r}-0.29 \\
(0.06)\end{array}$ & \\
\hline$\Delta \pi_{t}^{A G G}$ & $\begin{array}{r}4.47 \\
(0.69)\end{array}$ & $\begin{array}{r}4.46 \\
(0.70)\end{array}$ & & & & & $\begin{array}{r}4.89 \\
(0.66)\end{array}$ & $\begin{array}{r}3.92 \\
(0.49)\end{array}$ & $\begin{array}{r}3.90 \\
(0.50)\end{array}$ \\
\hline$r_{t, F E B-A U G}^{I N D} r_{t, F E B-A U G}^{A G G}$ & & $\begin{array}{r}0.22 \\
(0.05)\end{array}$ & & & & & & & $\begin{array}{r}0.24 \\
(0.04)\end{array}$ \\
\hline$\hat{g}_{t-1, A U G}^{2 n d}-\hat{g}_{t-1, F E B}^{2 n d}$ & $\begin{array}{r}0.16 \\
(0.04)\end{array}$ & $\begin{array}{r}0.17 \\
(0.04)\end{array}$ & $\begin{array}{r}0.12 \\
(0.06) \\
\end{array}$ & $\begin{array}{r}0.13 \\
(0.05) \\
\end{array}$ & $\begin{array}{r}0.15 \\
(0.05) \\
\end{array}$ & $\begin{array}{r}0.12 \\
(0.06) \\
\end{array}$ & $\begin{array}{r}0.17 \\
(0.04) \\
\end{array}$ & $\begin{array}{r}0.16 \\
(0.04) \\
\end{array}$ & $\begin{array}{r}0.17 \\
(0.04) \\
\end{array}$ \\
\hline$\overline{\mathrm{R} 2}$ & 0.26 & 0.25 & 0.09 & 0.10 & 0.14 & 0.09 & 0.23 & & \\
\hline
\end{tabular}




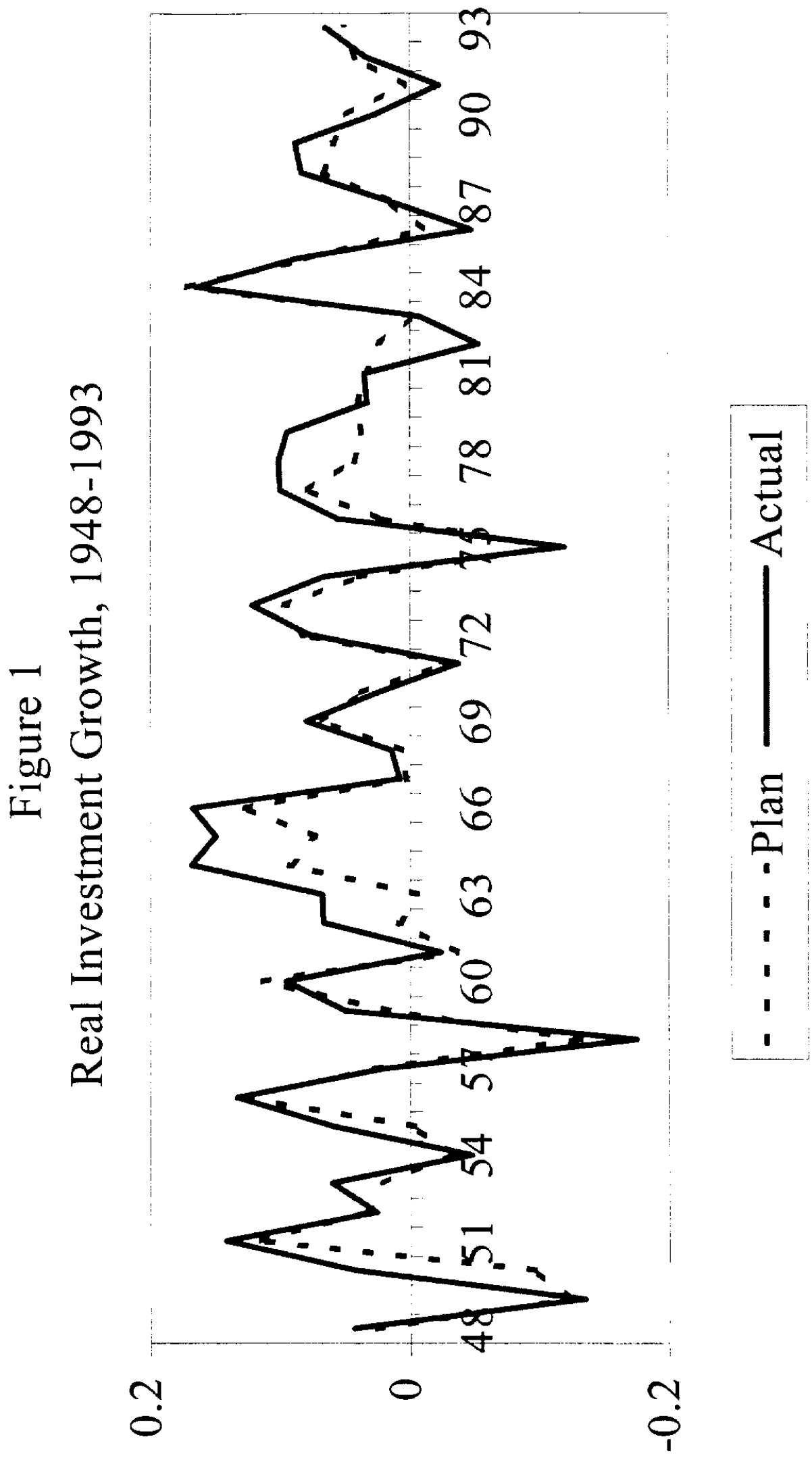




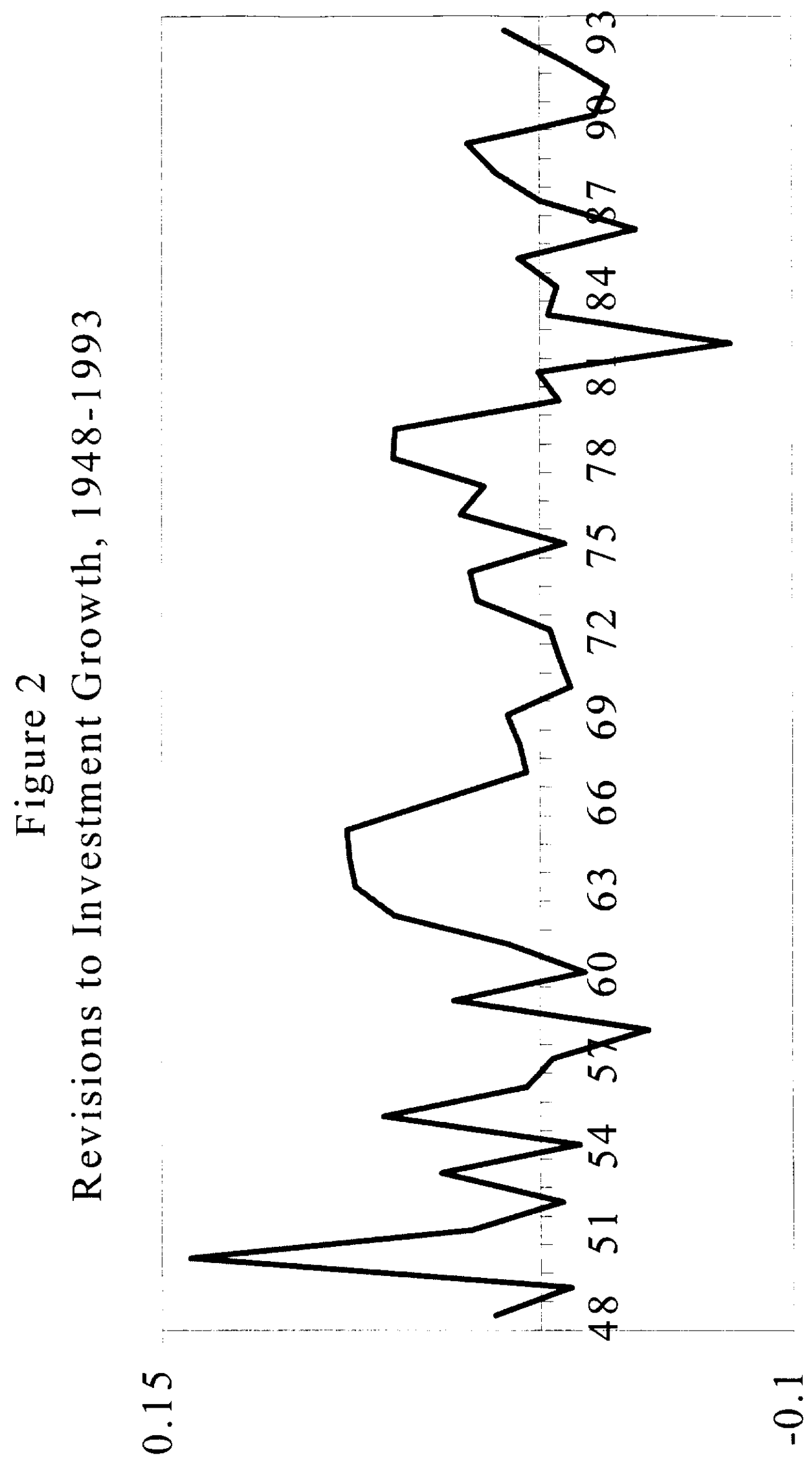

